\title{
Estimation of microbiological propagation and antimicrobial traits of the frequently accessible flowers
}

\author{
Marufa Sharmin, Kamal Kanta Das and Mrityunjoy Acharjee* \\ Department of Microbiology, Stamford University Bangladesh, 51 Siddeswari Road, Dhaka \\ 1217, Bangladesh
}

Received 30 May 2014/Accepted 28 July 2014

\begin{abstract}
Present study portrayed a complete microbiological profile of commonly available flowers including Rosa kordesii, Gladiolus hybrid, Acmella oleracea, Nyctanthes arbortristis and Pseudomussaenda flava which were randomly collected from Dhaka city, Bangladesh. The microbial contamination was quantified up to $10^{8} \mathrm{cfu} / \mathrm{g}$. Exploration of specific pathogenic bacteria was estimated within the range of $10^{3}$ to $10^{8} \mathrm{cfu} / \mathrm{g}$ of which Pseudomonas spp. was found in G. hybrid, A. oleracea and P. flava $\left(\sim 10^{6}\right.$ cfu/g), whereas Escherichia coli and Staphylococcal contamination was evident in almost all samples up to $10^{8} \mathrm{cfu} / \mathrm{g}$. The in vitro antimicrobial activities of the flower extracts were notable against most of the test bacteria. The ethanolic extracts of $R$. kordesii showed anti-bacterial activity against most of the bacteria except $E$. coli and Salmonella spp. G. hybrid extracts showed activity against Klebsiella spp. and Bacillus spp., A. oleracea against E. coli, Pseudomonas spp., Bacillus spp., Klebsiella spp., Staphylococcus spp. and Salmonella spp., P. flava against Pseudomonas spp. and Bacillus spp., and $N$. arbortristis against Bacillus spp. The methanol extracts of $G$. hybrid possessed activity against $E$. coli, Listeria spp. and Pseudomonas spp., $N$. arbortristis extracts against $E$. coli, Vibrio spp., Bacillus spp., Klebsiella spp. and Staphylococcus spp., P. flava extracts against $E$. coli.
\end{abstract}

Key words: Microbiological analysis; Flowers; Antimicrobial activity

Plants have the ability to synthesize a wide range of chemical components with numerous beneficial effects to treat human disease complications $(1,2)$. Apart from antibiotic therapy which is currently known to face the shortfall of drug- resistant microorganisms, use of herbal medicines gained its acceptance in recent days (3-11). Several studies have been reported to possess the antioxidant activity of plants with wound-healing effects as well as to prevent the formation and oppose the action of toxic radicals $(8,12-14)$. In global prospective, among the herbal products, uses of flower extracts for disease medication is not unlikely $(11,15)$.

Some common flowers like Hibiscus rosasinensis and Ixora cocconea have been reported to exhibit the antimicrobial activity against common pathogenic microorganisms (14, 16-20). Ipomoea digitata and Allmanda cathartic have long been used for the mitigation indigestion, tuberculosis, tumors, malaria and liver complications (21-23). However, along with their beneficial effects, microbiological contamination of flowers leading to disease commencement is a pitfall (24-26). Based on these facts, current investigation endeavored (i) to the simulation study of bacterial and fungal access to Rosa kordesii, Gladiolus hybrid,

†Corresponding Author. Mailing address: Mrityunjoy Acharjee, Department of Microbiology, Stamford University Bangladesh, 51 Siddeswari Road, Dhaka, Bangladesh; Email: mrityunjoy_111@yahoo.com.
Acmella oleracea, Nyctanthes arbortristis and Pseudomussaenda flava, and (ii) to unravel the in vitro antimicrobial activity of those flower extracts.

\section{MATERIALS AND METHODS}

Study area, sampling, sample processing and microbiological analysis. Five categories of flowers including $R$. kordesii, G. hybrid, A. oleracea, N. arbortristis and P. flava, were randomly collected during February 2013 to April 2013 following standard protocol (27). Samples were quickly transported to the laboratory, and prior to microbiological assay, $10 \mathrm{~g}$ of each sample was mixed with $90 \mathrm{ml}$ of buffer peptone water $(\mathrm{pH} 7.2 \pm 0.2)$ in 9:1 ratio and serially diluted up to $10^{-5}$

From the dilution $10^{-4}$ each of the samples $0.1 \mathrm{ml}$ was introduced on to the nutrient agar and Sabouraud dextrose agar for the isolation of total viable bacteria and fungi, respectively. Subsequently, MacConkey agar, Membrane Fecal Coliform agar (M-FC), Manitol Salt agar, Cetrimide agar and Actinomycetes agar were used as selective media for quantification of coliforms, fecal coliforms, Staphylococcus spp. Pseudomonas spp. and Actinomycetes, consecutively (28-32). All the inoculated plates were incubated at $37{ }^{\circ} \mathrm{C}$ for 24 hours except SDA plates, which were incubated at $25^{\circ} \mathrm{C}$ for 48 hours.

Solvent extraction. The dried parts (petals, steam and sepal) of each flower were first ground, and the fine powders were added to $120 \mathrm{ml}$ of ethanol and methanol in Durham's bottle which were kept in shaking water bath at $130 \mathrm{rpm}$ for $24 \mathrm{~h}$. at 20 ${ }^{\circ} \mathrm{C}$. Extracts were then concentrated in a rotary evaporator under reduced pressure. The dried residual extracts were dissolved in $10 \%$ dimethyl sulfoxide (DMSO) to a final concentration of $10 \mathrm{mg} / \mathrm{ml}(33-35)$. Samples were stored overnight at $-20{ }^{\circ} \mathrm{C}$ until use.

Assay of antimicrobial activity. The Mueller-Hinton agar (MHA) plates were prepared followed by modified agar well diffusion method $(31,32,36,37)$. Lawns of bacterial suspensions including Escherichia coli, Pseudomonas spp., Listeria spp., Vibrio spp., Klebsiella spp., Staphylococcus aureus, Bacillus spp. (turbidity compared with the McFarland standard) were prepared, wells $\left(8 \mathrm{~mm}^{3}\right)$ were made, and $100 \mu$ of the crude extract, ethanol- and methanol extracts at a concentration of $\sim 11.1 \mathrm{mg} / \mathrm{ml}$ each were introduced into the wells. Absolute ethanol, methanol and dimethyl sulfoxide $(10 \%)$ were used as negative controls while the antibiotic discs of gentamicin $(10 \mu \mathrm{l})$ were used as positive control. Plates were incubated at $37{ }^{\circ} \mathrm{C}$ for 12-18 hours and examined for formation of the zone of inhibitions ( $\mathrm{mm}$ ) 


\section{RESULTS AND DISCUSSION}

Previously our group unveiled the anti-bacterial traits of $H$. rosasinensis, I. cocconea, I. digitata and A. cathartic extracts (unpublished) which is in consistent to several other studies (18-20). Since these flowers are widely known to combat against a range of disease complications, we further turned our attention to extend such investigation on other flowers easily available in Bangladesh. One important aspect is that in the view of the study of inhabitant microflora in flowers and herbs, not so much studies have been reported so far. Our study showed that almost all samples exhibited huge gathering of spoiling bacterial and fungal flora (Table 1). G. hybrid, A. oleracea and P. flava were found to be contaminated with Pseudomonas spp. $\left(\sim 10^{6} \mathrm{cfu} / \mathrm{g}\right)$. E. coli and Staphylococcal contamination was extremely significant up to $10^{7}$ and $10^{8} \mathrm{cfu} / \mathrm{g}$, respectively in all the tested samples. No growth of actinomycetes and Klebsiella spp. was observed. To our knowledge, such a quantification of flower accessing microorganisms is for the first time in Bangladesh.

Anti-bacterial activity of flower extracts. Several studies revealed flower extracts to be inhibitory of growth of certain pathogens including E. coli, P. aeruginosa, S. aureus, B. subtilis, S. pneumoniae, and Enterobacter aerogens $(38,39)$. According to our study, the aqueous extract of G. hybrid and $N$. arbortristis were found to exhibit the bactericidal effects against Salmonella spp. (13mm) and Staphylococcus spp. (12mm) respectively, whereas extracts of $R$. kordesii, $A$. oleracea, $P$. flava showed no antimicrobial activity. The crude fraction and the residual extracts also showed no activity.

The ethanolic extracts of $R$. kordesii was found to form zone of inhibition against both Gram negative and Gram positive bacteria. However, no activity was scored against E. coli and Salmonella spp. (Table 2). In case of G. hybrid ethanol extract, the maximum activity was found on Klebsiella spp. and Bacillus spp. whereas no antibacterial activity was coined against others (Table 3 ).

The extracts of $A$. oleracea was found to be effective against E. coli, Pseudomonas spp., Bacillus spp., Klebsiella spp., Staphylococcus spp. and Salmonella spp. while Vibrio spp. and Listeria spp. were found to be resistant (Table 4). N. arbortristis was found to be active only against Bacillus spp. (Table 5) whereas the ethanolic extract of $P$. flava was active against Pseudomonas spp. and Bacillus spp. (Table 6).

Likewise, the methanol extracts of G. hybrid showed the anti-bacterial activity with the inhibition zones of $14 \mathrm{~mm}$, $13 \mathrm{~mm}$ and $10 \mathrm{~mm}$ against E. coli, Listeria spp. and Pseudomonas spp. consecutively (Table 3). The extracts of $N$. arbortristis were found to inhibit the growth of $E$. coli, Vibrio spp., Bacillus spp., Klebsiella spp. and Staphylococcus spp. (Table 5). P. flava extracts were found active only against $E$. coli (Table 6) while the extracts of $R$. kordesii and A. oleracea were inactive

TABLE 1. Microbiological profile of flower samples

\begin{tabular}{cccccc}
\hline Samples & $\begin{array}{c}\text { TVB } \\
(\mathbf{c f u} / \mathbf{g})\end{array}$ & $\begin{array}{c}\text { Fungi } \\
(\mathbf{c f u} / \mathbf{g})\end{array}$ & $\begin{array}{l}\text { E. coli } \\
(\mathbf{c f u} / \mathbf{g})\end{array}$ & $\begin{array}{c}\text { Staphylococcus spp. } \\
(\mathbf{c f u} / \mathbf{g})\end{array}$ & $\begin{array}{c}\text { Pseudomonas spp. } \\
(\mathbf{c f u} / \mathbf{g})\end{array}$ \\
\hline Rosa kordesii $(\mathrm{n}=5)$ & $3.2 \times 10^{8}$ & $4.4 \times 10^{8}$ & $2.2 \times 10^{6}$ & $2.6 \times 10^{8}$ & 0 \\
Gladiolus hybrids $(\mathrm{n}=5)$ & $6.5 \times 10^{8}$ & $3.5 \times 10^{8}$ & $5.0 \times 10^{5}$ & $4.4 \times 10^{8}$ & $2.2 \times 10^{6}$ \\
Acmella oleracea $(\mathrm{n}=5)$ & $3.4 \times 10^{8}$ & $3.6 \times 10^{8}$ & $3.9 \times 10^{4}$ & $3.7 \times 10^{8}$ & $4.1 \times 10^{3}$ \\
Nyctanthes arbortristis $(\mathrm{n}=5)$ & $5.0 \times 10^{8}$ & $4.8 \times 10^{8}$ & $4.4 \times 10^{7}$ & $2.0 \times 10^{8}$ & 0 \\
Pseudomussaenda flava $(\mathrm{n}=5)$ & $4.8 \times 10^{8}$ & $3.2 \times 10^{8}$ & $1.0 \times 10^{6}$ & $2.2 \times 10^{8}$ & $4.2 \times 10^{5}$ \\
\hline
\end{tabular}

TVB $=$ Total viable bacteria

The average microbial load has been shown in the table. Fecal coliform and Klebsiella spp. and actinomycetes were completely absent in all samples.

The experiment has been done in triplicate and the result was reproducible.

TABLE 2. Antimicrobial activity of Rosa kordesii extracts

\begin{tabular}{|c|c|c|c|c|c|c|c|}
\hline \multirow[b]{2}{*}{ Test bacteria } & \multicolumn{7}{|c|}{ Zone of Inhibition in diameter (mm) } \\
\hline & $\begin{array}{l}\text { Crude } \\
\text { fraction }\end{array}$ & $\begin{array}{l}\text { Negative } \\
\text { control } \\
(\mathrm{BPW}) \\
\end{array}$ & $\begin{array}{l}\text { Negative } \\
\text { control } \\
\text { (Ethanol) } \\
\end{array}$ & $\begin{array}{l}\text { Ethanol } \\
\text { extract }\end{array}$ & $\begin{array}{c}\text { Negative } \\
\text { control } \\
\text { (Methanol) }\end{array}$ & $\begin{array}{c}\text { Methanol } \\
\text { extract }\end{array}$ & $\begin{array}{c}\text { Positive control } \\
(\text { Gentamicin } 10 \mu \mathrm{g})\end{array}$ \\
\hline E. coli & 0 & 0 & $8 \mathrm{~mm}$ & 0 & 0 & 0 & $16.80 \mathrm{~mm}$ \\
\hline Pseudomonas spp. & 0 & 0 & 0 & $21 \mathrm{~mm}$ & 0 & 0 & $28.44 \mathrm{~mm}$ \\
\hline Vibrio spp. & 0 & 0 & 0 & $14 \mathrm{~mm}$ & 0 & 0 & $18.01 \mathrm{~mm}$ \\
\hline Bacillus spp. & 0 & 0 & $7 \mathrm{~mm}$ & $11 \mathrm{~mm}$ & 0 & 0 & $22 \mathrm{~mm}$ \\
\hline Klebsiella spp. & 0 & 0 & 0 & $12 \mathrm{~mm}$ & 0 & 0 & $18.83 \mathrm{~mm}$ \\
\hline Staphylococcus spp. & 0 & 0 & 0 & $18 \mathrm{~mm}$ & 0 & 0 & $22 \mathrm{~mm}$ \\
\hline Listeria spp. & 0 & 0 & 0 & $10 \mathrm{~mm}$ & 0 & 0 & $23.00 \mathrm{~mm}$ \\
\hline Salmonella spp. & 0 & 0 & 0 & 0 & 0 & 0 & $29.22 \mathrm{~mm}$ \\
\hline
\end{tabular}


TABLE 3. Antimicrobial activity of Gladiolus hybrid extracts

\begin{tabular}{cccccccc}
\hline & \multicolumn{7}{c}{ Zone of Inhibition in diameter $(\mathbf{m m})$} \\
\cline { 2 - 7 } Test bacteria & $\begin{array}{c}\text { Crude } \\
\text { fraction }\end{array}$ & $\begin{array}{c}\text { Negative } \\
\text { control } \\
(\mathrm{BPW})\end{array}$ & $\begin{array}{c}\text { Negative } \\
\text { control } \\
\text { (Ethanol) }\end{array}$ & $\begin{array}{c}\text { Ethanol } \\
\text { extract }\end{array}$ & $\begin{array}{c}\text { Negative } \\
\text { control } \\
\text { (Methanol) }\end{array}$ & $\begin{array}{c}\text { Methanol } \\
\text { extract }\end{array}$ & $\begin{array}{c}\text { Positive control } \\
\text { (Gentamicin } 10 \mu \mathrm{\mu g})\end{array}$ \\
\hline E. coli & 0 & 0 & $8 \mathrm{~mm}$ & $11 \mathrm{~mm}$ & 0 & $14 \mathrm{~mm}$ & $16.80 \mathrm{~mm}$ \\
Pseudomonas spp. & 0 & 0 & 0 & 0 & 0 & $10 \mathrm{~mm}$ & $28.44 \mathrm{~mm}$ \\
Vibrio spp. & 0 & 0 & 0 & 0 & 0 & 0 & $18.01 \mathrm{~mm}$ \\
Bacillus spp. & 0 & 0 & $7 \mathrm{~mm}$ & $10 \mathrm{~mm}$ & 0 & 0 & $22 \mathrm{~mm}$ \\
Klebsiella spp. & 0 & 0 & 0 & $12 \mathrm{~mm}$ & 0 & 0 & $18.83 \mathrm{~mm}$ \\
Staphylococcus spp. & 0 & 0 & 0 & 0 & 0 & 0 & $22 \mathrm{~mm}$ \\
Listeria spp. & 0 & 0 & 0 & 0 & 0 & $13 \mathrm{~mm}$ & $23.00 \mathrm{~mm}$ \\
Salmonella spp. & 0 & 0 & 0 & 0 & 0 & 0 & $29.22 \mathrm{~mm}$ \\
\hline
\end{tabular}

TABLE 4. Antimicrobial activity of Acmella oleracea extracts

\begin{tabular}{|c|c|c|c|c|c|c|c|}
\hline \multirow[b]{2}{*}{ Test bacteria } & \multicolumn{7}{|c|}{ Zone of Inhibition in diameter (mm) } \\
\hline & $\begin{array}{l}\text { Crude } \\
\text { fraction }\end{array}$ & $\begin{array}{c}\text { Negative } \\
\text { control } \\
(\mathrm{BPW})\end{array}$ & $\begin{array}{l}\text { Negative } \\
\text { control } \\
\text { (Ethanol) }\end{array}$ & $\begin{array}{c}\text { Ethanol } \\
\text { extract }\end{array}$ & $\begin{array}{c}\text { Negative } \\
\text { control } \\
\text { (Methanol) }\end{array}$ & $\begin{array}{c}\text { Methanol } \\
\text { extract }\end{array}$ & $\begin{array}{c}\text { Positive control } \\
(\text { Gentamicin } 10 \mu \mathrm{g})\end{array}$ \\
\hline E. coli & 0 & 0 & $8 \mathrm{~mm}$ & $11 \mathrm{~mm}$ & 0 & 0 & $16.80 \mathrm{~mm}$ \\
\hline Pseudomonas spp. & 0 & 0 & 0 & $12 \mathrm{~mm}$ & 0 & 0 & $28.44 \mathrm{~mm}$ \\
\hline Vibrio spp. & 0 & 0 & 0 & 0 & 0 & 0 & $18.01 \mathrm{~mm}$ \\
\hline Bacillus spp. & 0 & 0 & $7 \mathrm{~mm}$ & $11 \mathrm{~mm}$ & 0 & 0 & $22 \mathrm{~mm}$ \\
\hline Klebsiella spp. & 0 & 0 & 0 & $11 \mathrm{~mm}$ & 0 & 0 & $18.83 \mathrm{~mm}$ \\
\hline Staphylococcus spp. & 0 & 0 & 0 & $11 \mathrm{~mm}$ & 0 & 0 & $22 \mathrm{~mm}$ \\
\hline Listeria spp. & 0 & 0 & 0 & 0 & 0 & 0 & $23.00 \mathrm{~mm}$ \\
\hline Salmonella spp. & 0 & 0 & 0 & $15 \mathrm{~mm}$ & 0 & 0 & $29.22 \mathrm{~mm}$ \\
\hline
\end{tabular}

TABLE 5. Antimicrobial activity of Nyctanthes arbortristis extracts

\begin{tabular}{|c|c|c|c|c|c|c|c|}
\hline \multirow[b]{2}{*}{ Test bacteria } & \multicolumn{7}{|c|}{ Zone of Inhibition in diameter (mm) } \\
\hline & $\begin{array}{l}\text { Crude } \\
\text { fraction }\end{array}$ & $\begin{array}{l}\text { Negative } \\
\text { control } \\
(\mathrm{BPW})\end{array}$ & $\begin{array}{c}\text { Negative } \\
\text { control } \\
\text { (Ethanol) }\end{array}$ & $\begin{array}{c}\text { Ethanol } \\
\text { extract }\end{array}$ & $\begin{array}{c}\text { Negative } \\
\text { control } \\
\text { (Methanol) }\end{array}$ & $\begin{array}{c}\text { Methanol } \\
\text { extract }\end{array}$ & $\begin{array}{c}\text { Positive control } \\
\text { (Gentamicin } 10 \mu \mathrm{g})\end{array}$ \\
\hline E. coli & 0 & 0 & $11 \mathrm{~mm}$ & 0 & 0 & $12 \mathrm{~mm}$ & $16.80 \mathrm{~mm}$ \\
\hline Pseudomonas spp. & 0 & 0 & 0 & 0 & 0 & 0 & $28.44 \mathrm{~mm}$ \\
\hline Vibrio spp. & 0 & 0 & 0 & 0 & 0 & $11 \mathrm{~mm}$ & $18.01 \mathrm{~mm}$ \\
\hline Bacillus spp. & 0 & 0 & $11 \mathrm{~mm}$ & $11 \mathrm{~mm}$ & 0 & $13 \mathrm{~mm}$ & $22 \mathrm{~mm}$ \\
\hline Klebsiella spp. & 0 & 0 & 0 & 0 & 0 & $12 \mathrm{~mm}$ & $18.83 \mathrm{~mm}$ \\
\hline Staphylococcus spp. & 0 & 0 & 0 & 0 & 0 & $11 \mathrm{~mm}$ & $22 \mathrm{~mm}$ \\
\hline Listeria spp. & 0 & 0 & 0 & 0 & 0 & 0 & $23.00 \mathrm{~mm}$ \\
\hline Salmonella spp. & 0 & 0 & 0 & 0 & 0 & 0 & $29.22 \mathrm{~mm}$ \\
\hline
\end{tabular}

TABLE 6. Antimicrobial activity of Pseudomussaenda flava extracts

\begin{tabular}{|c|c|c|c|c|c|c|c|}
\hline \multirow[b]{2}{*}{ Test bacteria } & \multicolumn{7}{|c|}{ Zone of Inhibition in diameter (mm) } \\
\hline & $\begin{array}{l}\text { Crude } \\
\text { fraction }\end{array}$ & $\begin{array}{l}\text { Negative } \\
\text { control } \\
(\mathrm{BPW})\end{array}$ & $\begin{array}{l}\text { Negative } \\
\text { control } \\
\text { (Ethanol) }\end{array}$ & $\begin{array}{c}\text { Ethanol } \\
\text { extract }\end{array}$ & $\begin{array}{c}\text { Negative } \\
\text { control } \\
\text { (Methanol) }\end{array}$ & $\begin{array}{c}\text { Methanol } \\
\text { extract }\end{array}$ & $\begin{array}{c}\text { Positive control } \\
(\text { Gentamicin } 10 \mu \mathrm{g})\end{array}$ \\
\hline E. coli & 0 & 0 & $8 \mathrm{~mm}$ & 0 & 0 & $14 \mathrm{~mm}$ & $15 \mathrm{~mm}$ \\
\hline Pseudomonas spp. & 0 & 0 & 0 & $14 \mathrm{~mm}$ & 0 & 0 & $14 \mathrm{~mm}$ \\
\hline Vibrio spp. & 0 & 0 & 0 & 0 & 0 & 0 & $18 \mathrm{~mm}$ \\
\hline Bacillus spp. & 0 & 0 & $7 \mathrm{~mm}$ & $11 \mathrm{~mm}$ & 0 & 0 & $22 \mathrm{~mm}$ \\
\hline Klebsiella spp. & 0 & 0 & 0 & 0 & 0 & 0 & $18.83 \mathrm{~mm}$ \\
\hline Staphylococcus spp. & 0 & 0 & 0 & 0 & 0 & 0 & $22 \mathrm{~mm}$ \\
\hline Listeria spp. & 0 & 0 & 0 & 0 & 0 & 0 & $15 \mathrm{~mm}$ \\
\hline Salmonella spp. & 0 & 0 & 0 & 0 & 0 & 0 & $16 \mathrm{~mm}$ \\
\hline
\end{tabular}


against all the test bacteria (Table 2 and Table 4 ).

From our findings, it is evident that the in vitro antimicrobial activities of the flower extracts, especially after ethanol treatment, were prominent against microorganisms. Also, interestingly the ethanol extract of all the samples exhibited antimicrobial activity against Bacillus spp. Presence of antimicrobial activity in the solvent extracts of the flower samples tested could possess the potential of being source of commercially dispensable herbal antimicrobial agents against different topical and enteric diseases (39-41).

\section{CONCLUSION}

A large number of studies have been carried out so far to detect the microbiological contamination level in flowers and others herbs; nevertheless, the sustainable capacity of such contamination is still now difficult to understand. Our study revealed a complete profile of microbial contamination in flower and measured the anti-bacterial activity of their ethanol and methanol extracts. The findings may largely assist to design a model for the development of new herbal medicines thereby augmenting the public health safety.

\section{ACKNOWLEDGEMENTS}

Authors are thankful to Stamford University Bangladesh for providing with financial aid and logistic supports.

\section{REFERENCES}

1. Kennedy, D. O., and E. L. Wightman. 2011. Herbal extracts and phytochemicals: plant secondary metabolites and the enhancement of human brain function. Advance in Nutrition 2: 32-50.

2. Davies, J., and D. Davies. 2010. Origins and evolution of antibiotic resistance. Microbiology and Molecular Biology 74: 417.

3. Bhalodia, N. R., P. B. Nariya, and V. J. Shukla. 2011. Antibacterial and antifungal activity from flower extracts of Cassiafistula L: An ethnomedicinal plant. International Journal of PharmTech Research 3: 160-168.

4. Figueroa, B. E. B., et al. 2011. Antibacterial activity of flower extracts from Helenium mexicanum H.B.K. Emirates Journal Food Agriculture 23: 258-264.

5. Kowti, R., et al. 2010. Antimicrobial activity of ethanol extract of leaf and flower of Spathodea campanulata P. Beauv. Research Journal of Pharmaceutical, Biological and Chemical Sciences 1 (3): 691.

6. Damery, S., et al. 2011. The use of herbal medicines by people with cancer: a cross-sectional survey. British Journal of Cancer 104: 927-933.

7. Ernst, E. 2011. Herbal medicine in the treatment of rheumatic diseases. Rheumatic Diseases Clinics of North America 37: 95-102.

8. Kucekova, Z., M. Jiri, H. Petr, and R. Otakar. 2013. Edible flowers antioxidant activity and impact on cell viability. Central European Journal of Biology 8: 1023-1031.

9. Mendes, E., M. T. Herdeiro, and F. Pimentel. 2010. The use of herbal medicine therapies by cancer patients. Alternative Medicine Report 23: 901-908.

10. Pahune, B., et al. 2013. Antimicrobial Activity of Clitoria ternatea L. flower extract and use as a natural indicator in acid base titration. Indian Journal of Natural Products and Resources 3: 48-51.

11. World Health Organization (WHO). 2013. WHO traditional medicine strategy: 2014-2023. World Health Organization Press, Geneva, Switzerland

12. Yamasaki, H., H. Uefuji, and Y. Sakihama. 1996. Stress proteins and myocardial protection. Arch. Biochem. Biophys. 332: 183-186.
13. Nayak, B. S., A. L. Udupa, and S. L. Udupa. 1999. Effect of Ixora coccinea flowers on dead space wound healing in rats. Fitoterapia 70: 233-236.

14. Gauthaman, K. K., et al. 2006. Cardioprotective effect of the Hibiscus rosasinensisflowers in an oxidative stress model of myocardial ischemic reperfusion injury in rat. BMC Complementary and Alternative Medicine 6: 32.

15. Kumari, K., and S. Gupta. 2013. Phytopotential of Catharanthus roseus L(G.) Don. Var. "Rosea" and "Alba" against various pathogenic microbes in vitro. International Journal of Research in Pure and Applied Microbiology 3: 77-82.

16. Birari, R. B., et al. 2009. Anti-inflammatory, analgesic and antipyretic effect of Hibiscus rosa-sinensis Linn Flower. Pharmacology online 3: 737-747.

17. Tomar, V., P. Kannojia, K. N. Jain, and K. S. Dubey. 2010. Antinoceceptive and anti -inflammatory activity of leaves of Hibiscus - rosasinensis. International Journal of Research in Ayurveda and Pharmacy 1: 201205 .

18. Kumar, L., G. Chakraborthy, V. Singh, and A. Mazumder. 2012. Hibiscus rosasinensis: A review on divine herb. Journal of Advances in Pharmacy and Healthcare Research 2: 9-18.

19. Ruban, P., and K. Gajalakshmi. 2012. In vitro antibacterial activity of Hibiscus rosa-sinensis flower extract against human pathogens. Asian Pacific Journal Tropical Biomedicine 2: 399-403.

20. Patel, R., A. Patel, V. Dharmesh, and N. Anju. 2012. Antimicrobial evaluation of hibiscus rosa-sinensis plant extracts against some pathogenic bacteria. Bulletin of Environmental and Scientific Research 1: 14-17.

21. Vartika, J., S. K. Verma and S. S. Katewa. 2010. Therapeutic validation of Ipomoea digitata tuber (Ksheervidai) for its effect on cardio vascular risk parameters. Indian Journal of Traditional Knowledge 10: 617-623.

22. Joselin, J., T. S. S. Brintha, A. R. Florence, and S. Jeeva. 2012. Screening of select ornamental flowers of the family Apocynaceae for phytochemical constituents. Asian Pacific Journal of Tropical Disease 2: S260-S264.

23. Mali, D., S. Singh, Y. Joshi, and V. Kadam. 2011. Hepatoprotective activity of tuberous root of Ipomoea digitata linn. against carbon tetrachloride induced hepatotoxicity. International journal of pharmaceutical sciences and research 2: 1034-1039.

24. Siegman-Igra, Y., et al. 1986. Should potted plants be removed from hospital wards. Journal of Hospital Infection 7: 82-5.

25. Kates, S. G., K. J. McGinley, E. L. Larson, and J. J. Leyden. 1986 Indigenous multiresistant bacteria from flowers in hospital and nonhospital environments. American Journal Infection Control 19: 156-61.

26. Center for Disease Control and Prevention (CDC). 2003. Guideline for Environmental Infection Control in Health-Care Facilities. Centers for Disease Control and Prevention, Atlanta.

27. American Public Health Association (APHA). 1998. Standard Methods for the Examination of Water and Wastewater. American Public Health Association, Washington DC.

28. Cappuccino, J. G., and N. Sherman. 1996. Microbiology - A laboratory manual. The Benjamin/Cummings Publishing Co Inc, California.

29. Noor, R., et al. 2013. Microbiological analysis of major sea fish collected from local markets in Dhaka city, Bangladesh. The Journal of Microbiology, Biotechnology and Food Sciences 2 (4): 2420-2430.

30. Acharjee, M., E. Ahmed, S. K. Munshi, and R. Noor. 2014. Validation of $\gamma$-irradiation in controlling microorganisms in fish. Nutrition and Food Science 44 (3): 258-266.

31. Ahmed, T., et al. 2014. Assessment of microbiological proliferation and in vitro demonstration of the antimicrobial activity of the commonly available salad vegetables within Dhaka metropolis, Bangladesh. Am. J. Agri. Forestr. 2 (3): 55-60.

32. Sharmin, M., et al. 2014. Microbiological profiling and the demonstration of in vitro anti-bacterial traits of the major oral herbal medicines used in Dhaka Metropolis. SpringerPlus 3: 739 .

33. Tahera, J., et al. 2014. Demonstration of anti-bacterial activity of commonly available fruit extracts in Dhaka, Bangladesh. Ame. J. Microbiol. Res. 2 (2): 68-73.

34. Senjuti, J. D., et al. 2014. Assessment of microbiological contamination and the in vitro demonstration of the anti-bacterial traits of the commonly available local fruit blend within Dhaka Metropolis. J. Pharmacog. Phytochem. 3 (1): 73-77.

35. Arullappan, S., Z. Zakaria, and D. F. Basri. 2009. Preliminary screening of antibacterial activity using crude extracts of Hibiscus rosa sinensis. Tropical Life Sciences Research 20: 109-118.

36. Jagessar, R. C., A. Mars, and G. Gones. 2008. Selective antimicrobial properties of leaf extract against various micro-organisms using Disc diffusion and Agar well diffusion method. Journal of Natural Science 6: 2438.

37. Hussain, A., S. Wahab, I. Zarin, and M. D. S. Hussain. 2010. Antibacterial activity of the leaves of Cocciniaindica (W and A) of India. Advance Biological Research 4: 241-248. 
38. Hirulkar, N. B., and M. Agrawal. 2010. Antimicrobial activity of rose petals extract against some pathogenic bacteria. International Journal of Pharmaceutical and Biological Archives 1: 478-484.

39. Mishra, R. P., M. Arshad, and A. Sami. 2011. Antibacterial Properties of Rosa indica (L.) Stem, Leaves and Flowers. Journal of Pharmaceutical and Biomedical Sciences 12 (15): 1-3.
40. Rajagopal, K., K. Sasikala, and B. Ragavan. 2008. Hypoglycemic and antihyperglycemic activity of Nymphaea stellata flowers in normal and alloxan diabetic rats. Pharm. Biol, 12: 654-659.

41. Dash, B. K., et al. 2013. Antibacterial activity of Nymphaea nouchali (Burm. f) flower. Annals of Clinical Microbiology and Antimicrobials 12: 27 